УАK 070:654.197

ББК 76.032

DOI 10.22394/1682-2358-2020-3-24-31

A.A. Korobov, Doctor of Sciences (Politics), Professor of the Political Sciences Department, Povolzhsky Institute of Management named after P.A. Stolypin, Branch of the Russian Presidential Academy of National Economy and Public Administration

A.A. Ryabov, Master student of the Faculty of Communications, Media and Design, National Research University "Higher School of Economics"

\section{NEWS AGENCIES} AS AGENTS OF STATE INFORMATION POLICY (Case Study of "TASS" and "Russia Today")

Peculiarities of implementing information policy of the Russian Federation by the news agencies "TASS" and "Russia Today" are considered. Theoretical analysis of the concepts of "state information policy" and "information agency" is carried out. Features of functioning of the news agencies "TASS" and "Russia Today" and the degree of their participation in implementing the state information policy of Russia are characterized.

Key words and word-combinations: state information policy, information agencies, information.
A.A. Коробов, доктор политических наук, профессор кафедрь политических наук ПоВолжского института упраВления имени П.А. Стольтина - филиала Российской академии народного хозяйства и государственной служби при Президенте РФ (email: aakorobov@inbox.ru)

A.A. Рябов, махистрант факультета коммуникаиий, медиа и дизайна Национального исследовательского университета «Высшая школа экономики» (email: art1896ryaboff@yandex.ru)

\section{ИНФОРМАЦИОННЫЕ} АГЕНТСТВА КАК ПРОВОАНИКИ ГОСУААРСТВЕННОЙ ИНФОРМАЦИОННОЙ ПОАИТИКИ

\section{(на примере ТАCС и МИА «Россия сегоАня»)}

Аннотация. Рассматриваются особенности реализации государственной информационной политики РФ информационными агентствами «ТАСС» и «Россия сегодня». Проводится теоретический анализ понятий «государственная информационная политика» и «информационное агентство». Дается характеристика особенностей функционирования информационных агентств «ТАСС» и «Россия сегодня» и степени их участия в реализации государственной информационной политики России.

Ключевые слова и словосочетания: государственная информационная политика, информационные агентства, информация.

B современном мире роль информаџии и массовых коммуникаций в регулировании 
общественных отношений, взаимодействия государства и институтов гражданского общества весьма велика и продолжает непрерывно расти. Только за последние несколько мет скорость распространения информации и площадь охвата аудитории информацией возросли многократно, что отразилось в целом на уровне информированности граждан. ОАновременно с развитием информационных технологий растет и степень их проникновения в общество, в резуиьтате чего все большее количество мюдей становятся участниками массово-коммуникационных процессов. В такой интенсивно развивающейся системе массовых коммуникаций дмя того, чтобы государство, граждане, их разнообразные объединения и отдельные социальные группы имели возможность равнощенного пубцичного диалога, а государство также могло еще и в полной мере отстаивать свои национальные интересы в информационной сфере, разрабатывается и реализуется специальный комплекс мер - так называемая «государственная информационная политика». Если же процессы массовой коммуникации (то есть процессы производства и целенаправленного распространения сведений средствами массовой коммуникации) используются в качестве ключевого механизма воздействия государства на массовое сознание в современном обществе, то субъекты государственной информационной политики в этом сложном механизме играют роль непосредственных акторов влияния на образ действий и политическое сознание граждан.

Подобная картина наблюдается сегодня во всех странах мира с хотя бы минимальным уровнем развития информационно-коммуникационных техномогий. Россия в этом плане не является искиючением. В стране прослеживается четко выработанная информационная политика государства, предусматривающая ее реализацию не только через средства массовой информации, но и через государственные институты масс-медиа. Отметим, что институт массмедиа является одним из важнейших проводников государственной информаџионной политики, и в частности это касается информаџионных агентств. ОАной из отличительных черт информационных агентств как вида масс-медиа явцяется то, что они выступают агрегаторами и распространителями разАичного рода актуальной и Аостоверной информаџии. И самое главное - ее первичными распределительными узмами дмя других СМИ. Более того, информационные агентства явцяются на текущий момент самым оперативным из традиционных видов средств массовой коммуникации (СМК), проигрывая в этом плане только соџиальным медиа. А это означает, что большое число средств массовой информации не будет иметь возможности полноџенно функщионировать без существования информационных агентств, посколыку многие СМИ получают в ежеАневном потоке огромное количество единиц оперативной и достоверной информации именно от информационных агентств, на основе которой они уже и создают собственные медиапродукты. Исходя из этого можно считать, что информационные агентства явцяются центрацьным звеном функционирования отечественной медиасистемы; и в первую очередь Аанный тезис касается государственных информационных агентств.

Вначаме заострим внимание на сути понятия «информационное агентство». В научной митературе отсутствует однозначное определение Аанной категории. 
На наш взгляд, самым удачным явмяется определение термина «информационные агентства» Т.И. Фроловой и Г.В. Вирена: «это специализированные предприятия $<\ldots>$, основными функциями которых явцяются сбор, обработка и распространение новой оперативной информации: политической, экономической, соџиальной, культурной» [1, с. 25-26] .

Термин «государственная информационная политика» (ГИП) интерпретируется учеными в узком и широком смысле слова. В первом случае под государственной информационной политикой понимается «способность и возможность субъектов политики воздействовать на сознание, психику мюдей, их поведение и деятельность с помощью информации в интересах государства и гражданского общества» [2]. В более широком смысле государственная информационная политика воспринимается как «особая сфера жизнедеятельности Аюдей, связанная с воспроизводством и распространением информации, удовлетворяющей интересы государства и гражданского общества, и направценной на обеспечение творческого, конструктивного Аиалога межАу ними и их представителями» [2]. Информационная политика сама по себе имеет Авойственную природу. С одной стороны, она предполагает решение технических задач по информатизации общества, а с Аругой стороны, информационная политика несет в себе гуманитарный компонент, поскольку определяется интересами граждан, власти и общества. Таким образом, можно сделать вывод о том, что структура государственной информационной политики преАставлена в виде двух ее основных компонентов: технического, подразумевающего под собой технологическое развитие и совершенствование информационной среды государства, а также доступа к ней; и содержательного, выражающегося в сбалансированном по своему приоритету информаџионном освещении актуальных дия всего общества информационных поводов и тем.

Отметим, что сегодня в России отсутствует единый документ, регламентирующий принципы реализации государственной информационной политики. Реализаџия ГИП регулируется сразу несколькими законодательными актами - это прежле всего федеральные законы: «О средствах массовой информации», «Об информации, информационных технологиях и защите информации», «О связи» и т.п. Аействует и Государственная программа Российской Федерации «Информаџионное общество (2011-2020 годы)» в ее последней версии «Информационное общество», утвержденной постановлением Правительства РФ от 29 марта 2019 г. № 356-24, цемью которой является улучшение качества жизни и работы граждан, а также условий функционирования организаций, совершенствование экономического потенциала страны на основе применения информационных и телекоммуникационных технологий. Успешно реализуется Стратегия развития информационного общества в Российской Федерации на 2017-2030 годы, цель которой состоит в создании условий Аля формирования в Российской Федераџии общества знаний. Оба последних доктринальных Аокумента разрабатывацись на Аолгосрочную перспективу и вкцючици в себя множество конкретных задач и конкретных целевых показателей.

В структурно-функциональном плане реализаџия государственной информаџионной политики возАожена на широкий круг органов государственного 
управления и профильных министерств, ведомств, одним из которых является Министерство цифрового развития, связи и массовых коммуникаций Российской Федерации (Минкомсвязь России). Но ведущая роль в процессе реализации данной политики все же отведена средствам массовой коммуникации и средствам массовой информации, в частности государственным федеральным СМИ. ОАна из ярких отличительных особенностей таких средств массовой коммуникации и информации состоит в том, что их деятельность в значительном объеме финансируется из средств государственного бюджета. Такая практика обусловлена тем обстоятельством, что государственные СМК и СМИ призваны распространять свои медиапродукты на максимально широкую аудиторию и освещать максимально широкий круг значимых Аця всего общества тем и информационных поводов. Отметим, что в силу большого объема требуемых дия этого финансовых средств частным средствам массовой коммуникации и информации преАставцяются крайне затруднительными организация и обеспечение необходимой ресурсной базы Амя реацизаџии Аанного процесса.

Нельзя утверждать, что государственные информагентства обладают особыми привилегиями по отношению к Аругим, не государственным, информагентствам и СМИ в плане производства, получения и воспроизводства информации. Но в силу своего статуса, а именно права сообщать значимую информацию от имени государства, им необходимо проявцять более серьезное внимание к собцюдению профессиональных стандартов при работе с информацией. Нельзя игнорировать тот факт, что государство Аействительно может ставить ряд определенных задач перед учрежденными ими структурами массмедиа и их руководством, но при этом, согласно ст. 18 Ф3 «О среАствах массовой информации», учредитель не вправе вмешиваться в деятельность СМИ, за искиючением ряда случаев.

Среди некоторых зарубежных экспертов бытует мнение, что вмешательство того ици иного государства в деятельность его информационных агентств возможкно при помощи ряда организащионных мер:

- «регулирования и управления их деятельностью;

- контроля их финансов и собственности;

- косвенного ици прямого политического контроця» [3] .

На наш взгляд, ни в коем случае нельзя рассматривать постановку государством определенных задач учрежденным им информагентствам как интервенцию в их редакционную политику. Главной целью осуществления государственной информационной политики явцяется то, чтобы средства массовой информации прежле всего транслировали в информационном пространстве общенациональные интересы, а не только реализовывали те или иные цели отдельных социальных или корпоративных групп. Такую ситуацию можкно истолковать следствием действий государства по уравновешиванию информационного поля страны. При этом стремление государства выступить существенным игроком информационного пространства страны явмяется совершенно обоснованным, так как размичные государственные структуры обладают широким набором инструментов, позволяющих реализовывать положения 
государственной информационной политики. Как и во всем мире, в России существуют средства массовой информации, учрежденные самыми разными структурами или конкретными циџами. Но в случае, если каждая из этих структур будет моббировать в масс-медиа только выгодную себе информационную повестку, это можкет привести к серьезной дестабимизации социально-Политических отношений в государстве. Именно поэтому представляется крайне важным, чтобы государство учреждало собственные медиа, ведь таким образом у всех общественных институтов и соџиальных групп появится Аополнительная возможность полноџенного публичного диалога; парамлельно с этим государство сможет через свои информационные площадки последовательно реализовывать политику по защите национальных интересов в информационном пространстве и обеспечению общественной стабимьности.

Предметом исследование Аанной публикации является политика двух российских государственных информационных агентств: ТАСС и Международного информационного агентства (МИА) «Россия сегодня». Аанный выбор обусловлен тем, что обозначенные информаџионные агентства так или иначе принимают активное участие в реацизации государственной информационной политики в Российской Федерации, а также явцяются безусловными мидерами по цитируемости среди Аругих российских информационных агентств. Подтверждением тому являются данные сервиса «Медиалогия» [4], а также наличие профессионального термина «большая тройка информационных агентств», в которую входят ТАСС, МИА «Россия сегодня» и Интерфакс. Цель Аанного исследования - выявление специфики реализации информационными агентствами задач, определенных государственной информационной политикой Российской ФеАерации.

Аостижение этой цели предполагает последовательное решение следующих исследовательских задач:

- проведение теоретического анализа понятий «информационное агентство» и «государственная информационная политика»;

- рассмотрение нормативных правовых актов, опредемяющих принщипы и меры по реализации государственной информационной политики (ГИП) Российской Федерации;

- характеристика ключевых аспектов деятельности информационного агентства «ТАСС» и МИА «Россия сегодня» по реализации государственной информационной помитики.

ТАСС и МИА «Россия сегодня» обладают достаточно широкой сетью корреспондентских пунктов по всему миру: четырнадџать филиалов в России и 79 преАставительств более чем в шестидесяти странах мира у ТАСС и семьдесят представительств и два филиала в различных городах России и странах мира у МИА «Россия сегодня» [5; 6]. Оба информагентства предлагают своей аудитории широкую минейку медиапродуктов и услуг, основу которой составцяют разцичные информационные центы, в том числе на иностранных языках, фото-, видеоматериалы, интернет-ресурсы, пресс-конференции и другое. ТАСС и МИА «Россия сегодня» как государственные информагентства призваны обеспечивать максимацьное покрытие информационного поля как 
в виде распространения своих продуктов и услуг на как можно более широкую аудиторию, так и в виде информационного освещения максимально возможного количества тем и сфер жизни общества. Иными словами, ТАСС и МИА «Россия сегодня» в силу своего статуса обязаны освещать те темы и информационные поводы, которые, с точки частных информагентств, явцяются слабомонетезируемыми, но при этом их освещение представцяется крайне важным для общества. К такой тематике относится общественно-политическая сторона жизни социума, культура, образование, спорт и т.п. Именно в Аанном аспекте наиболее ярко раскрывается суть деятельности ТАСС и МИА «Россия сегодня» по реализации государственной информационной политики и отстаиванию национацьных интересов в информационном пространстве. Именно на эти цели ТАСС и МИА «Россия сегодня» получают внушительные по своему объему субсидии из федерального бюАжета. Под определенным углом зрения работу по охвату максимацьно большой аудитории, освещению широкого круга тем, созданию и содержканию разветвленной сети корреспондентских пунктов можно воспринимать как своеобразный многоплановый бизнес-процесс, требующий огромных финансовых ресурсов. Такими ресурсами не обладает почти ни одно частное российское СМИ (речь идет об объемах финансирования порядка нескольких мимииардов рублей в год).

Поскольку прямая деятельность ТАСС и МИА «Россия сегодня» касается не только непосредственно процессов создания, воспроизводства, аккумумирования и передачи свеАений из размичных областей жизнедеятельности человека, но и в определенной степени модернизации информационной инфраструктуры, технических каналов массовых коммуникаций - например, активно внедряются новые передовые и инновационные программные проАукты, позволяющие более эффективно распределять и распространять информацию по целевым аудиториям, - то эта деятельность подпадает под определенные подпрограммы Государственной программы «Информационное общество», в частности, подпрограмму «Информационная среда», цель которой состоит, согласно тексту документа, «в развитии информационной среды и обеспечении равного доступа населения к медиасреде» [7], а ее задачи своАятся к слеАующим положениям:

- постепенной полной оџифровке всех имеющихся в нацичии фондовых материалов;

- обеспечению безопасности информационных фондов и сохранности фондовых материалов (также подразумевается защита информационных ресурсов от несанкционированного доступа);

- «захвату» коммуникационного пространства информацией, пропаганАирующей традиционные культурные, нравственные и семейные ценности, зАоровый образ жизни, вызывающей потребность получения образования, мичностного роста, успеха, интереса к профессиональному росту, карьере;

- увеличению Аоли в медиасреде соџиально значимых проектов и их непрерывному развитию;

- созданию и подАержанию режима доступности дия граждан России актуацьной, Аостоверной, соџиацьно значимой информаџии о событиях в стране и мире [7]. 
Заслуживает внимания и финансовый аспект функционирования рассматриваемых государственных информационных агентств. Основные денежные среАства на деятельность ТАСС и МИА «Россия сегодня» поступают из федерального государственного бюджета России. Аля проведения дальнейшего исследования целесообразно обратиться к статьям расходов этого финансового документа. Цель выделения федеральных бюджетных средств информационному агентству ТАСС сформулирована как «финансовое обеспечение расходов по организации мероприятий по освещению государственной политики и общественной жизни в Российской Федерации» [8] .

В свою очередь, МИА «Россия сегодня» денежные средства выделяются преимущественно «в целях финансового обеспечения расходов по освещению за рубежом государственной политики Российской Федеращии и общественной жкизни в Российской Федерации, и обеспечению национальных интересов Российской Федерации в информационной сфере» [9]. ОАнако есть и џелый ряд иных целей выделения бюАжетных среАств МИА «Россия сегоАня» (причем этот список Ааже шире, чем у информационного агентства «ТАСС»), но все они - как и в предыдущем случае - «встроены» в главную цель финансирования агентства. Обратим внимание, что в обоих случаях наличие отдельных статей государственных расходов в федеральном бюджете свидетельствует о прямой заинтересованности государственной власти в реализации информаџионными агентствами «ТАСС» и МИА «Россия сегодня» государственной информационной политики Российской Федерации.

При сравнении направлений государственного финансирования медийной деятельности двух информационных агентств выявляется, что МИА «Россия сегодня» ведет несколько более широкую по своему профилю деятельность в информационно-коммуникационном пространстве, нежели информационное агентство «ТАСС», хотя цель, предмет и сфера медийной деятельности у них схожи. КАючевое отличие МИА «Россия сегодня» от ТАСС заключается в том, что его информационные продукты и медиауслуги в значительно большей степени направлены на зарубежную аудиторию; одним из подтвержАающих фактов этого может служить проект «Sputnik», осуществляющий свою деятельность на 32 языках.

Резюмируя изложенное, можно отметить, что реализация государственной информационной политики информационными агентствами «ТАСС» и МИА «Россия сегодня» осуществляется по следующим основным направлениям:

- освещение государственной политики, событий культуры, спорта, науки и обшественной жизни в Российской ФеАерации и за рубежом;

- реализаџия наџиональных интересов России в информаџионной сфере: создание соответствуюшей информаџионной повестки Аня, раскрытие тем под определенным углом зрения;

- обеспечение принципа свободы массовой информации, свободы мнений;

- расширение и совершенствование международного информаџионного обмена;

- развитие и модернизация информационного общества в России.

Все это еще раз подтверждает, что информационное агентство «ТАСС» 
и МИА «Россия сегодня» действительно являются активными участниками реализаџии, то есть по сути проводниками государственной информаџионной политики Российской Федерации. При этом они участвуют в реализации ГИП не только в ее содержательном аспекте, выражающемся в освещении широкого круга значимых дия общества тем, но и в техническом аспекте, связанном с внедрением в свою работу современных технологий и новых каналов связи с аудиторией, тем самым развивая российскую информационную среду.

\section{Библиографический список}

1. Вирен Г.В., Фролова Т.И. Информационные агентства. Как делаются новости: учебное пособие для студентов вузов. М., 2015.

2. Информационная политика: учебник / П.В. Беспалов, В.Б. Вепринцев, В.В. Воробьев [и др.]; под общ. ред. В.Д. Попова. М., 2003.

3. Juntunen L., Nieminen $H$. The Future of National News Agencies in Europe-case study 3: The Changing Relationship Between News Agencies and the State - 2019. URL: http://eprints.lse. ac.uk/100066/

4. Топ-3 самых цитируемых информационных агентств - 2019 г. URL: https://www.mlg. ru/ratings/media/federal/ $7130 /$

5. Устав ФГУП «Информационное телеграфное агентство России (ИTAP - TACC)». URL: https://base.garant.ru/6151827/53f89421bbdaf741eb2d1ecc4ddb4c33/

6. Устав ФГУП МИА «Россия сегодня». URL: http://www.fapmc.ru/rospechat/rospechat//wr/ unitar/item130.html

7. Об утверждении государственной программы Российской Федерации «Информационное общество»: постановление Правительства РФ от 15 апр. 2014 г. № 313. URL: https://base. garant.ru/70644220/

8. О федеральном бюджете на 2020 год и на плановый период 2021 и 2022 годов: Федер. закон от 2 дек. 2019 г. № 380-Ф3 (в ред. от 18 марта 2020 г.). URL: http://www.consultant.ru/ document/cons_doc_LAW_339305/2158d3f2d7087f5b2f5e6e30137e2d57bbc84103/

9. Об утверждении Правил предоставления из федерального бюджета субсидий Федеральному государственному унитарному предприятию «Международное информационное агентство "Россия сегодня"» / Федеральный портал проектов нормативных правовых актов. URL: https://regulation.gov.ru/ 